\title{
Description of the model
}

\section{"Th_differentiation_full_annotated_model_26May2010"}

This logical model integrates the documented cross-regulations between key transcription factors and the relevant signalling pathways controlling Th cell differentiation.

Using a reduction method and other analysis tools, we could show that this model generate specific stable states corresponding to canonical Th1, Th2, Th17 and Treg subtypes, which coexist with other transient hybrid cell types that co-express combinations of Th1, Th2, Treg and Th17 markers in an environment-dependent fashion.

The dynamical analysis of this model thereby provides novel insights into the heterogeneity and plasticity of late Th cell lineages.

Furthermore, this model enables in silico investigation of the nature of Th subtypes, as well as of potentially novel differentiation or reprogrammation pathways.

\begin{tabular}{|c|c|c|c|}
\hline Node ID & Val & Logical function & Comment \\
\hline $\mathrm{APC}$ & & Input component & $\begin{array}{l}\text { Antigen Presenting Cell. } \\
\text { This input node denotes proper presentation of an antigen } \\
\text { recognised by the Th TCR. }\end{array}$ \\
\hline IFNB_e & & Input component & $\begin{array}{l}\text { hugo:5434 } \\
\text { External source of interferon-beta. }\end{array}$ \\
\hline$\overline{I F N G \_\mathrm{e}}$ & & Input component & $\begin{array}{l}\text { hugo:5438 } \\
\text { External source of interferon-gamma. }\end{array}$ \\
\hline IIL2_e & & Input component & $\begin{array}{l}\text { hugo:6001 } \\
\text { External source of interleukine- } 2 \text {. }\end{array}$ \\
\hline$\overline{I I L 4 \_\mathrm{e}}$ & & Input component & $\begin{array}{l}\text { hugo:6014 } \\
\text { External source of interleukine- } 4 \text {. }\end{array}$ \\
\hline IIL6_e & & Input component & $\begin{array}{l}\text { hugo:6018 } \\
\text { External source of interleukine- } 6 \text {. }\end{array}$ \\
\hline IL10_e & & Input component & $\begin{array}{l}\text { hugo:5962 } \\
\text { External source of interleukine-10. }\end{array}$ \\
\hline IL12_e & & Input component & $\begin{array}{l}\text { a hugo:5969 } \\
\text { Exugo:5970 } \\
\text { External source of interleukine-12. }\end{array}$ \\
\hline |IL15_e & & Input component & $\begin{array}{l}\text { hugo:5977 } \\
\text { External source of interleukine-15. }\end{array}$ \\
\hline IL21_e & & Input component & $\begin{array}{l}\text { hugo:6005 } \\
\text { External source of interleukine- } 21 .\end{array}$ \\
\hline IL23_e & & Input component & $\begin{array}{l}\text { hugo: } 15488 \\
\text { External source of interleukine- } 23 \text {. }\end{array}$ \\
\hline IL27_e & & Input component & $\begin{array}{l}\text { (e hugo: } 19157 \\
\text { External source of interleukine- } 27 .\end{array}$ \\
\hline TGFB_e & & Input component & $\begin{array}{l}\text { 0 hugo: } 11766 \\
\text { External source of Transforming Growth Factor beta. }\end{array}$ \\
\hline CD28 & 1 & APC & $\begin{array}{l}\text { hugo: } 1653 \\
\text { CD28 provides a co-stimulatory signal to the TCR, required for } \\
\text { the activation of Th cells. }\end{array}$ \\
\hline$\overline{I F N B R}$ & 1 & IFNB_e & $\begin{array}{l}\text { hugo:5432 } \\
\text { Upon ligand binding, the IFN-beta receptor activates STAT1. }\end{array}$ \\
\hline$\overline{I F N G R}$ & 1 & $\begin{array}{l}\text { IFNGR1 \& IFNGR2 \& } \\
\text { (IFNG } \mid \text { IFNG e) }\end{array}$ & $\begin{array}{l}\text { The IFN-gamma receptor requires the IFNGR1 and IFNGR2 } \\
\text { subchains and activates STAT1 upon binding. }\end{array}$ \\
\hline
\end{tabular}




\begin{tabular}{|c|c|c|c|}
\hline IL2R & 2 & $\begin{array}{l}\text { CGC \& IL2RB \& !IL2RA \& (IL2 } \\
\text { IL2 e) } \\
\text { CGC \& IL2RB \& IL2RA \& (IL2 | } \\
\text { IL2 e) }\end{array}$ & $\begin{array}{l}\text { ref:Kim06 } \\
\text { The IL-2 receptor requires the CGC and IL2RB subchains, and } \\
\text { activates STAT5 upon binding. } \\
\text { The IL2RA subchain is needed for the high affinity response. }\end{array}$ \\
\hline IL4R & 1 & 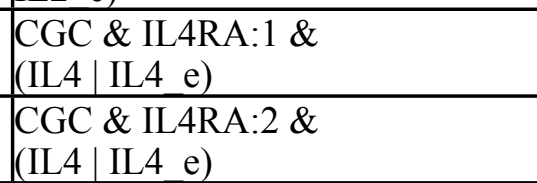 & $\begin{array}{l}\text { The IL-4 receptor requires the CGC and IL4RA subchains and } \\
\text { activates STAT6 and STAT5 upon binding. }\end{array}$ \\
\hline IL6R & 1 & GP130 \& IL6RA \& IL6_e & $\begin{array}{l}\text { The IL-6 receptor requires the IL6RA and GP130 subchains and } \\
\text { activates STAT3 upon binding. }\end{array}$ \\
\hline IL10R & 1 & $\begin{array}{l}\text { IL10RA \& IL10RB \& } \\
\text { (IL10| IL10 e) }\end{array}$ & $\begin{array}{l}\text { The IL-10 receptor requires the IL10RA and IL10RB subchains, } \\
\text { and activates STAT3 upon binding. }\end{array}$ \\
\hline IL12R & 1 & IL12RB1 \& IL12RB2 \& IL12_e & $\begin{array}{l}\text { ref:Kano2007 } \\
\text { The IL-12 receptor requires the IL12RB1 (at high level) and } \\
\text { IL12RB2 subchains and activates STAT4 upon binding. }\end{array}$ \\
\hline$\longdiv { I L 1 5 R }$ & 1 & $\begin{array}{l}\text { CGC \& IL15RA \& IL2RB \& } \\
\text { IL15 e }\end{array}$ & $\begin{array}{l}\text { The IL-15 receptor requires the CGC, IL15RA and IL2RB } \\
\text { subchains and activates STAT5 upon binding. }\end{array}$ \\
\hline IL21R & 1 & $\begin{array}{l}\text { GP130 \& CGC \& } \\
\text { (IL21 | IL21_e) }\end{array}$ & $\begin{array}{l}\text { hugo: } 6006 \\
\text { The IL-21 receptor requires the GP130 and CGC subchains, and } \\
\text { activates STAT3 upon binding. }\end{array}$ \\
\hline IIL23R & 1 & $\begin{array}{l}\text { GP130 \& IL12RB1 \& } \\
\text { (IL23 | IL23_e) \& STAT3 \& } \\
\text { RORGT }\end{array}$ & $\begin{array}{l}\text { hugo: } 19100 \\
\text { ref:Ivanov07 } \\
\text { The IL-23 receptor requires the GP130 and IL12RB1 subchains } \\
\text { and activates STAT3 upon binding. } \\
\text { According to (Ivanov et al, 2007), STAT3 and RORgt are needed } \\
\text { for its expression (most likely for the expression of its subchains). }\end{array}$ \\
\hline$\overline{I L 27 R}$ & 1 & GP130 \& IL27RA \& IL27_e & $\begin{array}{l}\text { The IL-27 receptor requires the IL27RA and GP130 subchains and } \\
\text { activates STAT1 and STAT3 upon binding. }\end{array}$ \\
\hline TCR & 1 & APC & T Cell Receptor, activated by antigen presentation. \\
\hline TGFBR & 1 & TGFB $\mid$ TGFB_e & Upon ligand binding, the TGF-beta receptor activates SMAD3. \\
\hline IFNGR1 & 1 & (basal value) & $\begin{array}{l}\text { hugo:5439 } \\
\text { IFNGR1 is a subchain of the IFN-gamma receptor. }\end{array}$ \\
\hline IFNGR2 & 1 & (basal value) & $\begin{array}{l}\text { hugo:5440 } \\
\text { IFNGR2 is a subchain of the IFN-gamma receptor. }\end{array}$ \\
\hline GP130 & 1 & (basal value) & $\begin{array}{l}\text { hugo:6021 } \\
\text { Glycoprotein } 130 \text { (IL-6 Signal Transducer) forms a complex with } \\
\text { binded receptor of the IL-6 familly. } \\
\text { It is required for signal transduction of these receptors (IL6R, } \\
\text { IL21R, IL23R and IL27R in this model). }\end{array}$ \\
\hline IL6RA & 11 & (basal value) & $\begin{array}{l}\text { IL hugo: } 6019 \\
\text { IL-6 receptor alpha is a subchain of the IL-6 receptor. }\end{array}$ \\
\hline IL12RB1 & $\frac{1}{2}$ & \begin{tabular}{|l} 
(basal value) \\
IRF1
\end{tabular} & $\begin{array}{l}\text { hugo:5971 } \\
\text { IL-12:Kano2007 } \\
\text { receptors. Accor beta } 1 \text { is a subchain of the IL-12 and IL-23 } \\
\text { level of IL12RB1, which is required for IL-12 signalling, but not } \\
\text { for IL-23. }\end{array}$ \\
\hline CGC & 1 & (basal value) & $\begin{array}{l}\text { The Common Gamma Chain (IL2RG), is shared by several } \\
\text { cytokine receptors (IL2R, IL4R, IL15R and IL21R). }\end{array}$ \\
\hline
\end{tabular}




\begin{tabular}{|c|c|c|c|}
\hline IL12RB2 & 1 & (basal value) & $\begin{array}{l}\text { hugo:5972 } \\
\text { ref:Mendoza06 } \\
\text { ref:Szabo1997b } \\
\text { IL-12 receptor beta } 2 \text { is a subchain of the IL-12 receptor. } \\
\text { According to (Szabo et al, 1997), STAT6 blocks the IL12 pathway } \\
\text { by inhibiting IL12RB2. }\end{array}$ \\
\hline IL10RB & 1 & (basal value) & IL10 receptor beta is a subchain of the IL-10 receptor. \\
\hline IL10RA & 1 & (basal value) & $\begin{array}{l}\text { hugo:5964 } \\
\text { IL10 receptor alpha is a subchain of the IL-10 receptor. }\end{array}$ \\
\hline \multirow[t]{2}{*}{ IL4RA } & 1 & !STAT5:2 & \multirow[b]{2}{*}{$\begin{array}{l}\text { hugo:6015 } \\
\text { http://www.ncbi.nlm.nih.gov/pubmed/18820682 } \\
\text { IL-4 receptor alpha is a subchain of the IL-4 receptor. } \\
\text { IL-2 upregulates IL4RA expression in a STAT5 dependent way } \\
\text { and thereby promotes augmented IL-4RA expression and priming } \\
\text { for responsiveness to IL4 (LIao et al, 2008). }\end{array}$} \\
\hline & 2 & STAT5:2 & \\
\hline IL15RA & 1 & (basal value) & $\begin{array}{l}\text { IL- } 15 \text { receptor alpha is a subchain of the IL- } 15 \text { receptor. } \\
\text { If }\end{array}$ \\
\hline IL2RB & 1 & (basal value) & IL-2 receptor beta is a subchain of the IL- 2 and IL-15 receptors. \\
\hline IL2RA & 1 & $\begin{array}{l}\text { (SMAD3 | FOXP3 | STAT5 | } \\
\text { NFKB) \& NFAT }\end{array}$ & $\begin{array}{l}\frac{\text { hugo: } 6008}{\text { ref:Kim06 }} \\
\text { IL-2 receptor alpha (CD25) is the high affinity subchain of the } \\
\text { IL-2 receptor. } \\
\text { According to (Kim et al, 2006), it is activated by NFAT, SMAD3, } \\
\text { NFKB and STAT5. } \\
\text { It is also activated by FOXP3 in CD4+CD25+ Treg. } \\
\text { Its presence enables higher activation of the IL-2 receptor. }\end{array}$ \\
\hline IL27RA & 1 & (basal value) & IL-27 receptor alpha is a subchain of the IL-27 receptor. \\
\hline IFNG & 1 & $\begin{array}{l}\text { proliferation \& !FOXP3 \& } \\
\text { !STAT3 \& NFAT \& } \\
\text { ((TBET \& RUNX3) | STAT4) }\end{array}$ & $\begin{array}{l}\text { hugo:5438 } \\
\text { ref:Djuretic2007 } \\
\text { ref:Bettelli2005 } \\
\text { The gamma interferon is produced by active Th1 cells. } \\
\text { Its production requires NFAT (blocked by FOXP3), cell } \\
\text { proliferation, and either IL12 (through STAT4) or Tbet (in } \\
\text { cooperation with RUNX3). } \\
\text { It is inhibited by STAT3. }\end{array}$ \\
\hline
\end{tabular}




\begin{tabular}{|c|c|c|c|}
\hline IL2 & 1 & $\begin{array}{l}((\text { NFAT \& !FOXP3) } \mid \text { NFKB }) \& ! \\
\text { (STAT5 \& STAT6) \& } \\
\text { !(NFKB \& TBET })\end{array}$ & $\begin{array}{l}\text { hugo:6001 } \\
\text { ref:Villarino2007 } \\
\underline{\text { ref:Rudensky2006 }} \\
\underline{\text { ref:Hwang2005 }} \\
\underline{\text { ref:Kim06 }} \\
\text { Inttp://www.ncbi.nlm.nih.gov/pubmed/12646638 } \\
\text { review, see Kim et al, 2006). } \\
\text { Its production requires NFAT (blocked by FOXP3) but not } \\
\text { proliferation (unlike assumed for other cytokines). } \\
\text { According to (Villarino et al, 2007), STAT5 (activated by } \\
\text { IL2/4/15) and STAT6 (activated by IL4) cooperate to inhibit IL2 } \\
\text { production. } \\
\text { RelA has been shown to induce IL-2 expression following } \\
\text { transient overexpression (Rao et al, 2003). } \\
\text { According to (Hwang et al, 2005), Tbet cooperates with relA (a } \\
\text { NFkB subunits to inhibit IL2. } \\
\text { Hence, the interaction from NFKB onto IL2 has a context- } \\
\text { dependent sign. }\end{array}$ \\
\hline IL4 & 1 & $\begin{array}{l}\text { NFAT \& proliferation \& GATA3 } \\
\& \text { !FOXP3 \& } \\
\text { !((TBET \& RUNX3) | IRF1) }\end{array}$ & $\begin{array}{l}\text { hugo:6014 } \\
\text { ref:Djuretic } 2007 \\
\text { ref:Bettelli2005 } \\
\text { ILef:Elser02 } \\
\text { IL is produced by Th2 cells. } \\
\text { Its production requires NFAT (blocked by FOXP3, see Bettelli et } \\
\text { al, 2005), proliferation and GATA3. } \\
\text { it is inhibited by Tbet (cooperating with RUNX3, see Djuretic et } \\
\text { al, 2007) and IRF1 (Elser et al, 2002). }\end{array}$ \\
\hline IL10 & 1 & $\begin{array}{l}\text { (GATA3 | STAT3) \& NFAT \& } \\
\text { proliferation }\end{array}$ & $\begin{array}{l}\text { hugo:5962 } \\
\text { ref:McGeachy07 } \\
\text { ref:Mendoza06a } \\
\text { Interleukine-10 is activated by GATA3 and STAT3. } \\
\text { As for other cytokines, its production requires NFAT and } \\
\text { proliferation. }\end{array}$ \\
\hline IL21 & 1 & NFAT \& proliferation \& STAT3 & $\begin{array}{l}\underline{\text { hugo: } 6005} \\
\underline{\text { ref:Korn07 }} \\
\text { ref:Zhou07 } \\
\text { Inter:Brenne } 2002 \\
\text { STAT3 (see Zhou et al, 2007). } \\
\text { As for other cytokines, their production requires NFAT and } \\
\text { proliferation. }\end{array}$ \\
\hline IL23 & 1 & NFAT \& proliferation \& STAT3 & $\begin{array}{l}\text { hugo: } 15488 \\
\text { ref:Zhou } 07 \\
\text { Interleukines } 21 \text { and } 23 \text { are sequentially activated by IL6 through } \\
\text { STAT3 (see Zhou et al, 2007). } \\
\text { As for other cytokines, their production requires NFAT and } \\
\text { proliferation. }\end{array}$ \\
\hline TGFB & 1 & NFAT \& proliferation \& FOXP3 & $\begin{array}{l}\text { hugo: } 11766 \\
\text { TGF-beta is believed to be important in regulation of the immune } \\
\text { system by Treg cells and apparently block the activation of } \\
\text { lymphocytes and some phagocytes. } \\
\text { The mechanism leading to its expression in Treg cells is unknown } \\
\text { Here, we assume an activation by FOXP3. }\end{array}$ \\
\hline
\end{tabular}




\begin{tabular}{|c|c|c|c|}
\hline TBET & 1 & (TBET | STAT1) \& !GATA3 & $\begin{array}{l}\text { hugo:11599 } \\
\text { ref:Mendoza06 } \\
\text { T-bet (TBX21) is the main transcription factor of the Th1 lineage. } \\
\text { It is activated by STAT1, self-maintained and inhibited by GATA3. }\end{array}$ \\
\hline$\overline{\text { GATA3 }}$ & 1 & (GATA3 | STAT6) \& !TBET & $\begin{array}{l}\text { hugo: } 4172 \\
\text { ref:Mendoza06 } \\
\text { GATA3 is the main transcription factor of the Th2 lineage. } \\
\text { It is activated by STAT6, self-maintained and inhibited by Tbet. }\end{array}$ \\
\hline FOXP3 & 1 & $\begin{array}{l}\text { STAT5 \& NFAT \& } \\
\text { (FOXP3 | (SMAD3 \& !STAT1 \& ! } \\
(\text { STAT3 \& RORGT) })\end{array}$ & $\begin{array}{l}\text { hugo:6106 } \\
\text { ref:Pyzik07 } \\
\text { ref:Floess } 2007 \\
\text { ref:Yao2007 } \\
\text { Foxp3 is the main known marker of regulatory T cells. } \\
\text { It is activated by NFAT, TGF-beta (through Smad3, see Tone et al, } \\
\text { 2008) and STAT5 (see Yao et al, 2007). } \\
\text { It is inhibited by STAT1 (binding site observed in Floess et al, } \\
\text { 2007), STAT3 (Yao et al, 2007) and RORgt. } \\
\text { We asumme that Foxp3 can maintain its own expression (binding } \\
\text { sites observed in Floess et al, 2007) in presence of NFAT and } \\
\text { STAT5. } \\
\text { We also assume that STAT3 and RORgt cooperate to inhibit } \\
\text { Foxp3. }\end{array}$ \\
\hline NFAT & 1 & CD28 \& TCR & $\begin{array}{l}\underline{\underline{\text { hugo: } 7775}} \\
\underline{\text { hugo:7776}} \\
\text { The No:7777 } \\
\text { The Nuclear Factor of Activated T cells (NFAT) familly of } \\
\text { transcription factors encompass } 5 \text { members. } \\
\text { The nucleus localisation of NFATc1 to NFATc4 depends on the } \\
\text { presence of calcineurin (and thus of the TCR activation). } \\
\text { This node represents the presence of NFAT (and AP1) in the } \\
\text { nucleus. }\end{array}$ \\
\hline STAT1 & 1 & IFNBR | IFNGR | IL27R & $\begin{array}{ll}\text { hugo: } 11362 \\
\text { ref:Mendoza06 } \\
\text { ref:Weaver07 } \\
\text { STAT1 is activated by IL-27, IFN-beta and IFN-gamma receptors. } \\
\text { ref:Kamiya2004 }\end{array}$ \\
\hline STAT3 & 1 & $\begin{array}{l}\text { IL6R | IL10R | IL21R | IL23R | } \\
\text { IL27R }\end{array}$ & $\begin{array}{l}\text { hugo: } 11364 \\
\text { ref:Brenne2002 } \\
\text { ref:Mendoza06a } \\
\text { STAT3 is activated by IL-6, IL-21, IL-23, IL-27 and IL-10 } \\
\text { receptors. }\end{array}$ \\
\hline STAT4 & 1 & IL12R \& !GATA3 & $\begin{array}{l}\text { hugo: } 11365 \\
\text { ref:Mendoza06a } \\
\text { STAT4 is activated by IL-12 receptor and inhibited by GATA3. } \\
\text { Mendoza et al (2006) proposed it as intermediate in IFN-gamma } \\
\text { inhibition by GATA3. }\end{array}$ \\
\hline \multirow[t]{2}{*}{ STAT5 } & 1 & 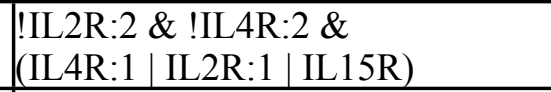 & \multirow{2}{*}{$\begin{array}{l}\text { hugo: } 11366 \\
\text { hugo:11367 } \\
\text { STAT5 is activated by IL-4, IL-15 and IL-2 receptors. } \\
\text { A high level of IL2R promotes a high level of STAT5, required to } \\
\text { activate cell proliferation. }\end{array}$} \\
\hline & 2 & IL2R:2 | IL4R:2 & \\
\hline
\end{tabular}




\begin{tabular}{|c|c|c|c|}
\hline STAT6 & 1 & IL4R & $\begin{array}{l}\text { hugo: } 11368 \\
\text { ref:Mendoza06 } \\
\text { STAT6 is activated by IL-4 receptor. }\end{array}$ \\
\hline SMAD3 & 1 & TGFBR & $\begin{array}{l}\text { hugo:6769 } \\
\text { SMAD3 is activated by TGF- beta receptor and involved in the } \\
\text { activation of IL2RA and FOXP3. }\end{array}$ \\
\hline IRF1 & 1 & STAT1 & $\begin{array}{l}\text { hugo:6116 } \\
\text { IRF1 is required for the activation of IL12RB1 and for the } \\
\text { inhibition of IL4 by STAT1. }\end{array}$ \\
\hline RUNX3 & 1 & TBET & $\begin{array}{l}\text { hugo: } 10473 \\
\text { ref:Djuretic } 2007 \\
\text { RUNX3 is activated by T-bet, with which it cooperates to activate } \\
\text { IFN-gama and inhibit IL- } 4 \text {. }\end{array}$ \\
\hline proliferation & 1 & STAT5:2 | proliferation & $\begin{array}{l}\text { ref:Morigg199 } \\
\text { ref:Bird98 } \\
\text { This component denotes that the cell proliferation has been } \\
\text { activated. } \\
\text { It is used as a switch required for the expression of most } \\
\text { cytokines. } \\
\text { It is activated by IL2 through STAT5 (see Moriggl et al, 1999). }\end{array}$ \\
\hline NFKB & 1 & !IKB \& !FOXP3 & $\begin{array}{l}\text { ref:Bettelli2005 } \\
\text { http://www.ncbi.nlm.nih.gov/pubmed/12646638 } \\
\text { Betkappa B is inhibited by I-kappa B and Foxp3 (according to } \\
\text { Bettelli et al, 2005). } \\
\text { The NF-kB family is composed is composed of NF-kB1, NF-kB2, } \\
\text { RelA, RelB and c-Rel. c-Rel has been solidly implicated in the } \\
\text { regulation of IL-2 transcription by chromatin remodelling accross } \\
\text { the IL-2 gene (Rao et al, 2003). Other components such as RelA } \\
\text { were shown to induce IL-2 expression following transient } \\
\text { overexpression. } \\
\text { Hence, the interaction from NFKB onto IL2 has a context- } \\
\text { dependent sign. }\end{array}$ \\
\hline IKB & 1 & |'TCR & $\begin{array}{l}\text { The NF-kappa B inhibitor I-kappa B is inhibited by the TCR } \\
\text { signal. }\end{array}$ \\
\hline RORGT & 1 & $\begin{array}{l}(\text { TGFBR \& STAT3) } \mid(\text { RORGT \& } \\
(\text { TGFBR | STAT3) })\end{array}$ & $\begin{array}{l}\text { ref:Zhou } 07 \\
\text { ref:Manel2008 } \\
\text { RORGT is a key actor in Th17 differentiation. } \\
\text { According to (Zhou et al, 2007), RORgt is activated by TGFb + } \\
\text { STAT3 (activated by interleukines 6, } 21 \text { and 23). } \\
\text { Here, we assume that RORgt is self-regulated (as the other master } \\
\text { regulators). }\end{array}$ \\
\hline IL17 & 1 & $\begin{array}{l}\text { NFAT \& proliferation \& RORGT } \\
\& \text { !FOXP3 \& } \\
\text { NFKB \& STAT3 \& } \\
\text { !(STAT5 | STAT } 1 \text { | STAT6) }\end{array}$ & $\begin{array}{l}\text { hugo:5981 } \\
\text { ref:Zhou2008 } \\
\text { IL17 cytokines are produced by TGFb+IL6 induced Th17 cells } \\
\text { when stimulated by IL23 and (IL18 or IL1b). } \\
\text { STAT3 and RORGT activate IL17 cooperatively. } \\
\text { The action of RORGT can be blocked by FOXP3 (Zhou et al, } \\
\text { 2008). STAT3 and NFkB are required to activate IL17. } \\
\text { IL2 inhibits IL17 through STAT5. STAT1, STAT5 and STAT6 can } \\
\text { bind on the IL17 promoter. } \\
\text { An inhibitory effect for Tbet and IL4 has also been reported. } \\
\text { Coexpression of IL17 and IFNg has been observed, indicating that } \\
\text { these inhibitions may be overcomed. }\end{array}$ \\
\hline
\end{tabular}




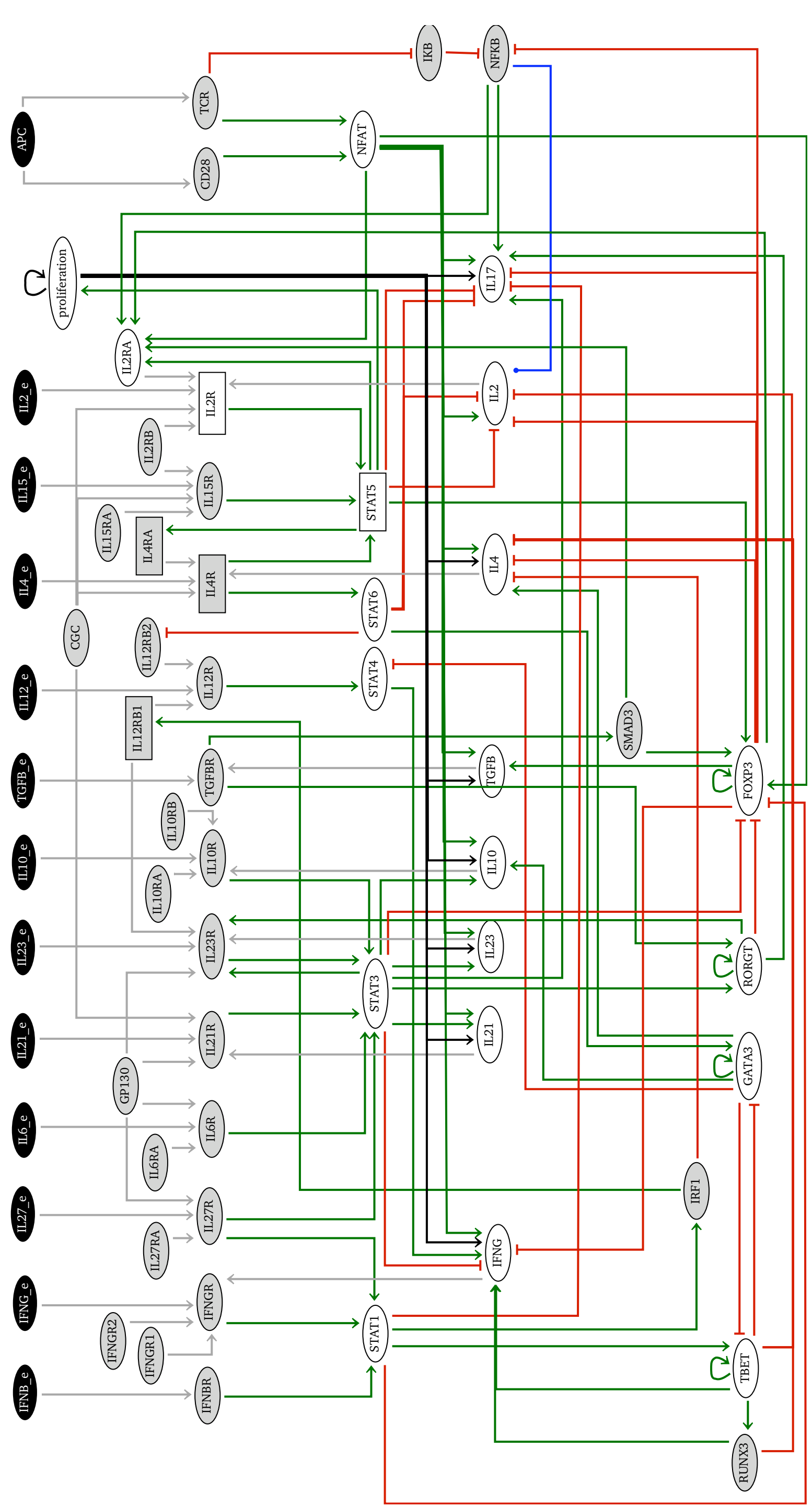

